\title{
A clash of gods - Conceptualising space in Daniel 1
}

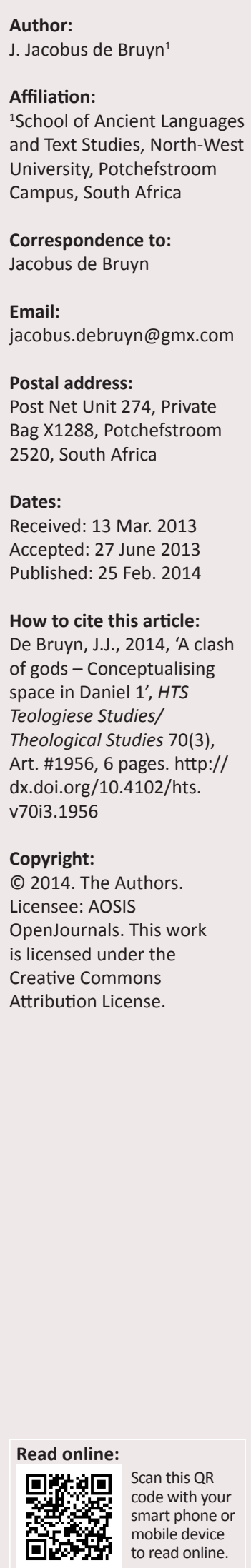

Applying cognitive linguistics to the text of Daniel 1 is a useful exegetical aid for a better understanding of the narrative. Studying the author's use of 'spatial markers' such as 'Jerusalem', 'Babylon', 'temple' and some other spatial features, makes it possible to reconstruct the narrative into a 'cognitive spatial frameset'. In this particular exegetical frameset, Daniel 1 can be described as a narrated confrontation between Yahweh and the gods of Babylon. Within this conflict between deities, Daniel, the divine agent becomes a spatial embodiment of Yahweh's power and authority to act inside a hostile, non-Israelite environment and at the same time undermines the authority of the Babylonian gods.

\section{Introduction}

'Space: the final frontier ...' this refrain ostensibly became a household catchphrase due to the long-standing popularity of the Star Trek science fiction franchise. This phrase emphasised man's desire to conquer the unknown universe. However, space can also be seen as a frontier in the quest to understand our (meaning we as humans) ${ }^{1}$ use of language and ultimately to improve our understanding of texts. The aim of this article is to specifically demonstrate how the use of a spatial-hermeneutical frameset can better our understanding of biblical texts.

Since the 1980s, researchers have developed a new approach when studying the language phenomenon and the way in which humans communicate. This new approach is known as cognitive linguistics. Briefly summarised, cognitive linguistics entails the study of the complex relationship between language and the mind (Evans, Bergen \& Zinken 2007:3). Cognitive linguistics differs mainly from other approaches by assuming that language reflects certain fundamental properties and design features of the human mind (Evans \& Green 2006:5). In this new cognitive approach to the study of language, it is shown that words denote, or symbolise, concepts (Croft \& Cruse 2004:7). Within such a paradigm of 'words equals concepts', this article will build on the theory that the concept of space forms an integral part of human cognition (Zlatev 2007:318). Together with time, space defines one of the most important basic conceptual domains of human thinking (Haspelmath 1997:1). According to cognitive linguistics, we use space to make sense of the world around us and thus space forms an integral part of the way in which we express ourselves (Zlatev 2007:318-319). It could even be said that all human behaviour is located in and constructed in terms of space (Low \& Lawrence-Zúñiga 2003:1).

Merleau-Ponty (2005:335-342) maintains that as we experience the environment around us, we construct spaces to help us make sense of the world we live in. If we climb a mountain it becomes possible to experience the fact that we are above other things that are now below us. By entering a building we experience the sensation that we are on the inside, whilst others are now perceived to be on the outside. We use these experiences to construct structural spaces through which we then categorise phenomena as being below, on top, inside, outside, under, et cetera. People whom we find disagreeable are categorised as those who are not close to us, whilst on the other hand, our friends are deemed as being close. We experience our homes and categorise these as private space and not everyone is welcome to enter this space. Some spaces, such as church or temple environments, are even experienced and treated as either holy or sacred spaces.

Through our experience and interaction with the world around us, space can thus be embodied in different entities or forms. This article will endeavour to show how the author(s) of Daniel 1 specifically employed the concept of sacred space to emphasise the universal authority and power of Yahweh.

If we aim to apply cognitive linguistics as a hermeneutical method to study biblical texts, it is important to note that texts (as written words) are mediums of communication (Becker 2005:45).

1.In this article the terms our, we or us are used as a reference to humans. For example: '... our understanding of texts;' or '... we use space to make sense of the world around us. 
Biblical texts are the product of written words. Therefore, as in the case of language, these texts are also embodied in the cognitive frameset of the people who wrote them. In terms of the aim of this article, this means that, if space forms such an integral part of human cognition, it is safe to say that the concept of space is also very prevalent when we communicate in written form. It is therefore important for biblical scholars to take note of cognitive linguistics if they want to improve their understanding of biblical texts. This article will attempt to show that a cognitive linguistic approach to the texts of the Hebrew Bible, particularly in the form of a spatial-hermeneutical frameset is indispensable to understand these texts more fully.

\section{Problem}

In the history of developing different exegetical approaches to biblical texts, the focus of such exegetical models range from studying the author, the texts themselves, as well as the first reader or listener (De Villiers 2006; Gerstenberger 1988; Hays \& Holladay [1982] 2007). In recent years much attention was given to the development of existential, redactional and canonical exegesis (Gorman 2001:16-20). In the development of exegetical approaches, it was recognised that biblical texts each had their own Gattung and Sitz im Leben. Therefore it is necessary to study not only the Umwelt (or Lebensraum) of texts, but also the Sprachwelt (Barton 1984:8; Hays \& Holladay 2007; Preuss 1984). Nevertheless, in spite of an increased focus - in the past and currently - on the study of the various biblical languages and their Sprachwelt, previously not much attention was given to cognitive linguistics as a hermeneutical model in the exegetical process of studying biblical texts. In short, the intention here is to explore the language of the texts as a mechanism used by the author to construct certain realities, even if they are only symbolic realities.

In this article the focus will be narrowed down to a cognitive linguistic approach to Daniel 1. As a broad overview beforehand, the main approaches to the book of Daniel can be summarised as follows:

- John Calvin (as translated by Myers in 1852) expounds the structure and literature of the text. He chooses as his Leitmotiv, Daniel's faithfulness to Yahweh.

- Aalders (1962) has an analytical, verse by verse approach.

- Hartman and Di Lella (1978) focus on the structure of the book, literature genres and their connection to the apocalyptic genre.

- Farrar (1979:351-432) provides a historical overview.

- Hindson and Kroll in the KJV Parallel Bible Commentary (1994:1627-1630) provide a verse by verse interpretation of the narrative without interpreting the narrative as a whole within its apocalyptical or historical contexts. As a result, this commentary does not consider an exposition of the language of the texts.

- Miller (1994) focuses on the language, literature and date, but no attention is given to the application of cognitive linguistics.

- Hayford (1995:210-214) interprets the narrative in terms of 'young men' who devote themselves to God. No attention is given to the underlying linguistic structure.

- Smith-Christopher (1996:17-153) pays much attention to the historical setting of the book. An excursion is given on food and power, but no connection is made to cognitive linguistics.

- Murphy (2002:152-163) recognises the book of Daniel as an apocalyptical work that is filled with symbolic references. He interprets Daniel 1 in the light of Jewish faithfulness to the Torah, despite continuous persecution.

- Steinmann (2008) highlights the unique form of the text as a work presented in two languages. He pays attention to the structure of the book and explores the themes of protection and of God versus the false gods, but he does not link these themes with a space framework.

- Witte (2012:643-657) emphasises the structure of the book. He summarises the theology of Daniel as follows: 'Daniel centres around the concept of $\mathrm{YHWH}$ as the director of time' (p. 644). Even though Witte acknowledges the time factor in his summary of Daniel, he does connect this theme with a spatial-hermeneutical frameset or any other aspects of cognitive linguistics.

This article will show that a cognitive linguistic approach to Daniel 1 might enhance biblical scholars' understanding of the texts.

\section{Methodology Spaces as embodied entities}

As stated in the introduction, space can be embodied in different forms or entities as we experience and interact with the world around us. Low and Lawrence-Zúñiga (2003:2) define embodied space as the location in which human experience and consciousness take material and spatial form. These embodied-space locations are used to understand places, movement and language. Scholars propose different indices of so-called spatial markers to identify different spaces within texts. Only a brief overview of these different types of spaces will be given below.

Low and Lawrence-Zúñiga (2003:1-37) identify the following spaces: the human body as a vessel of the self; body-space, which centres around the human body; gendered spaces; inscribed spaces; contested spaces and trans-national space. Jordan Zlatev (2007:318-350) identifies seven markers by which space can be categorised: trajectory; landmark; frame of reference; region; path; direction and motion. Some of these spaces will overlap. It is important to understand that the way in which we interact or experience these different spaces is defined by and imbedded in our worldview and culture (Low \& Lawrence-Zúñiga 2003:4-5). From this we can infer that spaces are symbols imbedded in the human mind or as Haspelmath (1997:1) remarked, conceptual domains of human thinking.

On a religious level, it is also possible to identify sacred space, seeing that religion forms part of human culture and mediates our interaction with the world (Murphy 2002:35-39). However, although sacred space can be distinguished - it 
usually overlaps with other types of spaces. Typically, the way in which a certain space is religiously experienced and associated with religious aspects, makes such a space holy or sacred. For example, a tree can form part of a forest or region, or it could be a landmark, but through a certain experience it can be set apart as a holy or sacred tree. The same could be said of a mountain. For instance, Mount Zion is not just a landmark in Israel, but it is also revered as a sacred or holy mountain. As a sacred mountain Zion could possibly be interpreted as the throne of God, the Israelite God (Ps 48) in Judaism, and is thus deemed as different from, for example, Table Mountain in South Africa. According to the Hebrew Bible the Temple differs from any other house, for it is revered as the house of Yahweh and therefore viewed as holy (cf. Ps 5:7-8, 79:1; Hab 2:20).

\section{Spatial-hermeneutical frameset}

As an approach to Daniel 1 a so-called spatial-hermeneutical frameset will be applied. Within this cognitive frameset the ancient worldview of the Hebrew Bible can be divided broadly into the natural world within which humans live, and the supernatural world of the gods (Murphy 2002:3539). The supernatural world, in turn, could be divided into the heavens above from where the gods rule over the world and the underworld as the world of the dead, but which also falls under the heavenly rule of the gods. For the purpose of this article we can distinguish two spaces: human space and divine or god-space. If we use the cognitive concept of body as an embodiment of space, we can describe it as a distinction between a heavenly body and an earthly body. This implies that the heavenly body is the vessel or space within which the gods usually live, and the earthly body designates the vessel or space in which humans live (see Figure 1).

Interaction between these two spaces was possible through a relationship that we can describe cognitively as sacred spaces within human space, or god-space within earthly space (see Figure 1). These sacred spaces could manifest from something as simple as a tree, river or mountain to a complex entity like a constructed building or city, or even the king's environment (Murphy 2002:35-49). These sacred spaces were viewed as extensions of the gods, or as heavenly space. The interaction that created these spaces, demonstrated that the earth falls under the authority of the divine.

In Old Testament times each nation usually had its own deity or pantheon of gods. Therefore it was believed that a god's authority and power on earth was confined to the national boundaries of the people who worshiped that specific deity (Walton 2006:97-102). Each pantheon of gods or deity thus established its own region of authority on earth. This ancient religious worldview not only formed part of the culture of ancient Israel, but it is also reflected in the text of the Hebrew Bible.

According to an alternative reading of Deuteronomy 32:8-9² the peoples of the earth were each given their own territory

2.'When the most High divided to the nations their inheritance, when he separated the sons of Adam, he set the bounds of the people according to the number of the children of Israel.'

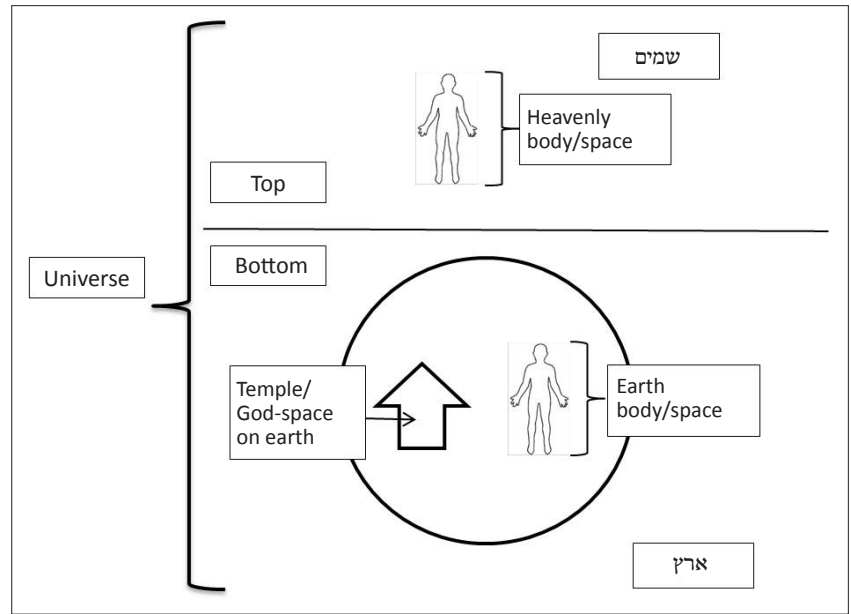

FIGURE 1: The universe of the Ancient Near Eastern depicted as different spaces.

according to the number of the gods. ${ }^{3}$ Thus each god possessed its own people (Murphy 2002:159). According to 1 Kings 20:23 the servants of the king of Aram informed him of the reason why they had lost in a previous battle against Israel. This was because they had fought Israel in the mountains and not on the plains, seeing that the Israelite god was considered here to be a mountain god. Thus the Arameans assumed that, as a mountain god the Israelite deity would not be as invincible in the plains as on the mountains. Israel in particular was seen as the holy or sacred property of Yahweh (Ex 19:5-6). Mount Zion was accepted as the holy throne of Yahweh (Ps 48) and Jerusalem as his holy city. The Temple in Jerusalem represents the cosmological balance that was created by Yahweh when he created heaven and earth. Thus the Temple was built to represent the heavenly dwelling of God that he founded over the ordered chaos as a symbol of his victory over the forces of chaos (cf. Ps 29; Murphy 2002:68). Thus, the Temple was considered a symbol of Yahweh's reign over both heaven and earth. The Temple also formed the boundaries of the deity's sacred heavenly space on earth (Albertz 2003:55, 133, 152-157; Murphy 2002:36-45; Walton 2006:113-135).

The Davidic king is also described as an earthly extension of the Israelite deity's rule. Not only is the Davidic king described as sitting at the right hand of Yahweh (Ps 110), but he is depicted as the son of Yahweh (Pss 2; 89:28) and sometimes is even called a god (Ps 45:8). The land of Israel was seen as the Holy Land and the territory beyond its borders was designated as the outside or profane world (Murphy 2002:46). This assessment is of course based on ancient Israel's religious experience of the city of Jerusalem, the Temple, Mount Zion and their king. Israel's religious experience was expressed in a religious worldview, which can be described as Zion theology. In Zion theology the Israelite God not only resided on Zion, he was the protector of Jerusalem. As the protector of Jerusalem, the Israelite God was seen as a powerful warrior who was impervious to the attacks of any opposing army. Thus, Zion was seen as unconquerable. At the same time Zion was seen as the centre of the Israelite (Jewish) collective identity (Hossfeld 3.See textual criticism on verse 8 in the Biblia Hebraica Stuttgartensia. 
\& Zenger 2005:515). Jerusalem and Zion were experienced as the axis mundi between heaven and earth (Humphreys 1990:61, 64-67). It means that in reading the texts, the city of Jerusalem or the Temple (or even other cities and temples) could be viewed not only as mere geographical landmarks, but also as an environment for humans to live in or to interact with God. These areas are depicted as sacred spaces based on the said religious worldview.

From the above, the following can be derived:

- Sacred spaces are extensions of heavenly space and could therefore be described as god-spaces on earth.

- Each deity was seen to have its own god-space.

- In Israel the Temple, Mount Zion, Jerusalem and the king were viewed as extensions of the Israelite deity's godspace.

- Israel was accepted as a holy land that fell directly under the rule of Yahweh.

- The territory beyond the borders of Israel was demarcated as the heathen or profane world.

\section{Applying the method Summary of Daniel 1}

In applying the cognitive frameset of spatial hermeneutics to the text of Daniel 1, it is important to highlight a few aspects of the narrative.

Verses 1-2: The king of Babylon, Nebuchadnezzar, captures the Judean (Israelite) city of Jerusalem. Nebuchadnezzar then takes the Judean king, Joachim, to Babylon as his prisoner. At the same time Nebuchadnezzar plunders the Temple of Yahweh. He carries off many of the Temple's objects and exhibits these items in the temple of his god in Babylon. This god probably was the Babylonian high-god Marduk, otherwise known as Bel (Abusch 1995:1014-1025).

Verses 3-7: The young men from the Davidic royal family are taken into the palace of Nebuchadnezzar to be brought up and educated as true Babylonians. The main character, Daniel, and his friends are given Babylonian names.

Verses 8-10: Daniel and his friends refuse to eat food from the king's table.

Verses 11-17: A period of ten days is set aside for Daniel and his friends to prove that their diet of vegetables is healthier than a diet of food taken from the king's table. At the end of the ten-day test, Daniel and his friends are not only healthier than the other young men, they are also shown to be more intelligent.

Verses 18-21: At the end of their education the young Judean men are brought before Nebuchadnezzar to be tested. Again, Daniel and his friends are not only found to be more astute and far wiser than the rest of the Judean young men, but they also outshine Nebuchadnezzar's personal counsellors.
In short, the narrative can be summarised as the story of four young Judean men from the Davidic royal house who struggle to maintain their Judean identity and faith within a profane and non-Israelite environment. Their deity provides a positive outcome in answer to their efforts to stay faithful to their Judean (Israelite) identity.

\section{A clash of deities}

Reading the text from within the cognitive frameset of space, there actually is much more to the narrative of Daniel 1 than merely the story of four boys trying to uphold their Judean culture within a hostile, foreign environment.

As indicated above, people of the ancient world believed that each deity had its personal region or territory over which it exerted its power and authority. In this way gods were bound to certain places, territories or cities. When nations waged war, each of them called upon their gods to protect them. If a nation lost a battle it was believed that this nation's gods were not strong enough to protect it. The fact was then also accepted that these gods and their territories of authority were from then on subject to the authority of the victor's gods. In the Hebrew Bible traces of this belief can be found in Psalm 137. In this section the Israelite exiles are mocked by their Babylonian captors and asked to sing songs of Zion, of the throne of Yahweh. However, the Israelites refused to sing their songs of worship in the land of foreign gods (Hossfeld \& Zenger 2005:515-516). According to Isaiah 36 the king of Assyria warns Hezekiah not to trust in Yahweh, for he could neither protect his city of Samaria nor could any other god protect their people against the king of Assyria and his god.

Keeping this in mind, the narrative of Daniel 1 could be summarised as follows. Yahweh's authority is challenged by an invasion of his god-space. The challengers are the Babylonian gods. Since verse 2 refers to Nebuchadnezzar's god, the probability can be accepted - for the sake of argument in this article - that these Babylonian gods were ruled and headed by Marduk, otherwise known as Bel (cf. Daniel's new name in verse 6), the supreme deity of Babylon (Abusch 1995:1014-1025).

In Daniel 1 Yahweh's god-space is marked by the following:

- the holy city of Jerusalem

- king Joachim and the royal families

- the Temple

- the land of Judea

- the character of Daniel.

By mentioning the royal families and Daniel's connection to them (vv. $3 \&$ 6), the author makes it possible for the character of Daniel to become the embodiment of Yahweh's rule (space), as in the case of the Judean king. The breach of Yahweh's god-space is marked by Marduk's king, Nebuchadnezzar ('Nebo protect my offspring' [Steinmann 2008:79]), who invades Jerusalem and plunders Yahweh's Temple. Yahweh's humiliation and inability to protect his jurisdiction, is emphasised strongly in the narrative. This 
is done by depicting the scenario in which Yahweh's king and royal families, as well as his Temple objects are taken to Marduk's base of strength, Marduk's city of Babylon and his temple.

In Babylon, Marduk's supremacy over Yahweh's people is accentuated. This dominance is denoted by the representation in which Daniel and his friends are to be stripped of their culture and identity as Yahweh's people by furnishing them with Babylonian names and providing them with a Babylonian education.

The following meanings can be attached to each name (Steinmann 2008:79, 88-89):

- Daniel: 'God is my Judge.'

- Belshazzar: 'may Bel protect his life.'

- Hananiah: 'Gracious is Yah.'

- Shadrach: 'The command of Aku.'

- Misha'el: 'Who is what God is.'

- Meshach: 'Who is what Aku is.'

- Azariah: 'Yah has helped.'

- Abednego: 'Servant of Nebo/Nergal.'

With their new names, Daniel and his friends are cognitively inscribed (Low \& Lawrence-Zúñiga 2003:1-37) or reproclaimed as vessels of the Babylonian gods. It means that the four Judeans are no longer the property of Yahweh, but the property of the Babylonian gods. However, the narrative of Daniel 1 takes an interesting turn. Yahweh is not as powerless within Marduk's territory as the people of ancient times may have expected. Marduk is suddenly challenged by Yahweh from within Marduk's own city. The challenge comes through what we can describe in terms a cognitive approach as a 'clash of foods or battle of the banquet'. Daniel and his friends refuse to eat the food coming from Nebuchadnezzar's table. Within a cognitive linguistic frameset, eating vegetables is a way for Daniel and his friends to set themselves apart as vessels through which Yahweh can act inside Marduk's god-space. By narrating the fact that Daniel and his friends prefer a different diet, the author establishes a base of operation for Yahweh within Marduk's god-space. In the absence of his king (the Davidic king is not present in the palace of Nebuchadnezzar), Yahweh utilises other members of the royal family to set up his own god-space in Marduk's territory. Despite their new names, Daniel and his friends refuse to act as vessels of the Babylonian gods, but continue to act as the property of Yahweh.

With Yahweh's help, Daniel manages to convince Ashpenaz, chief of the king's court officials, to assess the young men over a period of ten days. By mentioning that Yahweh helped Daniel, the author suggests to the reader the answer to the question: Will Marduk prevail as supreme ruler of his own territory? At the end of the ten-day food trial, which could otherwise be described as a clash of foods, the question of Marduk's supremacy is answered. The young men who had eaten from Nebuchadnezzar's table are not the healthiest or the most intelligent rather it was Daniel and his friends, who received their meals apart from the others. Thus, Yahweh is presented as the victor of the battle of the banquet. Yahweh's capability to undermine Marduk's authority on his own turf is emphasised when Ashpenaz decides to provide water and vegetables to all the young men and not only to Daniel and his friends (vv. 15-16).

The battle of the banquet is, however, only a preparation for a much tougher trial. At the end of their education, the young men still have to be tested by Nebuchadnezzar himself (vv. 18-20). Just as before the author narrates Yahweh's capability to operate within Marduk's god-space, seeing that Yahweh equips Daniel and his friends with Godly wisdom and insight (v. 17). Yahweh again is victorious, seeing that, as vessels of Yahweh, Daniel and his friends are found to be wiser and more intelligent, not only than all the other young men; they are also proven to be wiser and even more astute than Nebuchadnezzar's (and thus Marduk's) own counsellors.

At the end of the narrative it becomes clear: What started off as an invasion of Yahweh's god-space actually became a clever strategy to invade Marduk's own territory. When all of Yahweh's earthly property was carried off to Babylon, it was supposed to be a symbol of humiliation and subjection of Yahweh and his entourage to the rule of Marduk. However, at the end of the narrative in Daniel 1, the transfer of Yahweh's property to Babylon ironically turns into a strategic invasion of Marduk's own god-space.

By applying a spatial hermeneutical frameset to Daniel 1 the text's implication becomes clear: Yahweh's authority and rule is neither restricted to earthly god-spaces, nor subjected to human structures such as temples and national borders. In narrating his story within a spatial frameset, the author is demonstrating to his readers that Yahweh's rule is supreme, seeing that Yahweh can operate within the jurisdiction of other gods and they are unable to prevent him. In his own way the author is answering any doubts that people may have as to the authority of Yahweh. The Babylonian gods are exposed: they are not stronger than Yahweh. If Yahweh can operate in Marduk's city, he can act everywhere else. Therefore the exiles should not be afraid to sing Yahweh's praises, even within a profane and foreign world as it seems to them according to Psalm 137.

To put it even stronger, if Yahweh can operate within the profane world outside of his own original territory, the land of Israel, he can also protect his people within the profane world. In light of this assurance God's chosen people do not have to fear the profane world, neither other nations nor their gods who want to challenge Yahweh's rule on earth. The fact that Israel went into exile was not because of Yahweh's incapability to protect the Israelites. Rather, the exile happened because of Yahweh's own chosen actions towards his people. Yahweh himself delivered his people into the hands of Nebuchadnezzar. They were not defeated because Marduk was victorious over Yahweh. This fact the author already emphasises at the beginning of his narration (cf. v. 2). Yahweh has not forgotten his people and furthermore 
is not incapable of being present and operating in Babylon, as some may have thought at that time (cf. Is 40:27). On the contrary, Yahweh is omnipresent, seeing that his god-space is universal.

The book of Daniel was written to guide the Jews who lived under the rule of Antiochus IV Epiphanus and thus faced prosecution daily (Murphy 2002:152). For these Jews it meant that they should not fear the Hellenistic onslaught and the foreign gods. They were given the assurance: Even though they may suffer as a nation, Yahweh's rule was considered to be supreme and he would help and protect his people throughout their tribulation. The fact that Yahweh's temple was defiled and his high priest (Onias III) was assassinated by Antiochus IV (171 BCE), does not imply that Antiochus IV and his gods overpowered Yahweh (cf. Dn 9:25-26; 10:25-26; Murphy 2002:158-161). On the contrary, Yahweh carried his reign into new spatial frontiers.

\section{Conclusion}

If a spatial hermeneutical frameset is applied to the narrative of Daniel 1, it reveals a cognitive development in the religious thought of Israel. At first Yahweh's god-space was seen as limited to the tabernacle and the Arc of the Covenant, and later the Temple. Still later, Mount Zion, the Davidic king and Jerusalem became part of Yahweh's god-space. According to Daniel 1 the boundaries of Yahweh's god-space becomes universal. Yahweh operates where he chooses and anybody can be a vessel or an embodiment of Yahweh's action.

In his own way the author attempts to convince his readers that Yahweh's authority is universal, and not restricted to a particular spatial context.

Overall it can be concluded - as argued throughout this article - that applying some methodological features of cognitive linguistics to the texts of the Hebrew Bible can be beneficial when an attempt is made to better understand these texts. Indeed, this also emphasises the important role that cognitive linguistics can fulfil in the process of exegesis.

\section{Acknowledgements Competing interests}

The author declares that he has no financial or personal relationship(s) that may have inappropriately influenced him in writing this article.

\section{References}

Aalders, G.C., 1962, Daniël, Uitgeversmaatschappij J.H. Kok, Kampen.

Abusch, T., 1995, 'Marduk', in K. van der Toorn, B. Becking \& P.W. van der Horst (eds.), Dictionary of deities and demons in the Bible, E.J. Brill, Leiden, pp. 1014-1025.

Albertz, R., 2003, Israel in Exile: The history and literature of the sixth century B.C.E., transl. D. Green, Society of Biblical Literature, Atlanta, GA.

Barton, J., 1984, Reading the Old Testament: Method in biblical study, Darton Longman and Todd, London.

Becker, U., 2005, Exegese des Alten Testaments, Mohr Siebeck, Stuttgart.

Calvin, J., 1852, Commentaries on the book of the Prophet Daniel, transl. T. Myers, Calvin Translation Society, Edinburgh.

Croft, W. \& Cruse, D., 2004, Cognitive linguistics, University Press, Cambridge. http:// dx.doi.org/10.1017/CBO9780511803864

De Villiers, G., 2006, 'Oor eksegese en metodes: Die reëls van die spel', Old Testament Essays 19(3), 823-830.

Evans, V., Bergen, B. \& Zinken, J. (eds.), 2007, The cognitive linguistics reader, Equinox, London-Oakville.

Evans, V.C. \& Green, M., 2006, Cognitive Linguistics: An introduction, LEA, London.

Farrar, F.W., 1979, The Expositor's Bible, vol. 4., W. Robertson Nicoll (ed.), George H. Doran Company, New York, NY.

Fauconnier, G., 2007, 'Mental spaces', in D. Geeraets \& H. Cuyckens (eds.), The Oxford handbook of cognitive linguistics, pp. 351-376, Oxford University Press, Oxford.

Gerstenberger, E.S., 1988, 'Canon criticism and the meaning of Sitz im Leben', in D.L. Petersen, G.M. Tucker \& R.R. Wilson (eds.), Canon, Theology and Old Testament Interpretation, pp. 20-31, Fortress Press, Philadelphia, PA.

Gorman, M.J., 2001, Elements of biblical exegesis. A basic guide for students and ministers, Hendrickson Publishers, Philadelphia, PA.

Hartman, L.F. \& Di Lella, A.A., 1978, The book of Daniel, Doubleday \& Company, New York, NY.

Haspelmath, M., 1997, From space to time: Temporal adverbials in the world's languages, Lincom Europa, München/Newcastle.

Hayes, J.H. \& Holladay, C.R., [1982] 2007, Biblical exegesis: A beginner's handbook, 3rd edn., Westminster John Knox Press, Louisville, KY, London.

Hayford, J.W., 1995, Hayfords Bible handbook, Nelson Publishers, Vancouver, WA.

Hindson, E.E. \& Kroll, W.M., (eds.), 1994, The KJV parallel Bible commentary, Nelson Publishers, Vancouver, WA.

Hossfeld, F.L. \& Zenger, E., 2005, Psalms 3: A commentary on Psalms 101-150, Fortress, Minneapolis, MN. (Hermeneia).

Humphreys, W.L., 1990, Crisis and story. Introduction to the Old Testament, illustr. edn., McGraw-Hill, New York, NY.

Low, S.M. \& Lawrence-Zúñiga, D., 2003, The anthropology of space an place: Locating culture, Blackwell Publishing, Malden, MA.

Merleau-Ponty, M., 2005, Phenomenology of perception, transl. C. Smith, Routledge, New York, NY.

Miller, S.R., 1994, Daniel, Broadman \& Holman Publishers, Nashville, TN. (The New American Commentary, 18).

Murphy, F.J., 2002, Early Judaism: The exile to the time of Jesus, Hendrickson Publishers, Peabody, MA.

Preuss, H.D., 1984, Das Alte Testament in christlicher Predigt, Kohlhammer, Stuttgart.

Smith-Christopher, D.L., 1996, 'The book of Daniel', in L.E. Keck (ed)., The new interpreter's Bible, vol. vii, pp. 17-152, Abingdon Press, Nashville, TN.

Steinmann, A.E., 2008, Daniel, Concordia Publishing House, Saint Louis, MO.

Walton, J.H., 2006, Ancient Near Eastern thought and the Old Testament. Introducing the conceptual world of the Hebrew Bible, Baker Academic, Ada, MI.

Witte, M., 2012, 'The book of Daniel', in J.C. Gertz, A. Berlejung, K. Schmid \& M. Witte (eds.), T\&T Clark handbook of the Old Testament, pp. 643-668, T\&T Clark, New York, NY.

Zlatev, J., 2007, 'Spatial Semantics', in D. Geeraets \& H. Cuyckens (eds.), The Oxford handbook of cognitive linguistics, pp. 318-350, Oxford University Press, Oxford. 